\title{
Langerhans Cell
}

National Cancer Institute

\section{Source}

National Cancer Institute. Langerhans Cell. NCI Thesaurus. Code C12584.

Dendritic clear cells in the epidermis, containing distinctive granules that appear rod- or racket-shaped in section, but lacking tonofilaments, melanosomes, and desmosomes; they carry surface receptors for immunoglobulin (Fc) and complement (C3), and are believed to be antigen fixing and processing cells of monocytic origin; active participants in cutaneous delayed hypersensitivity. 